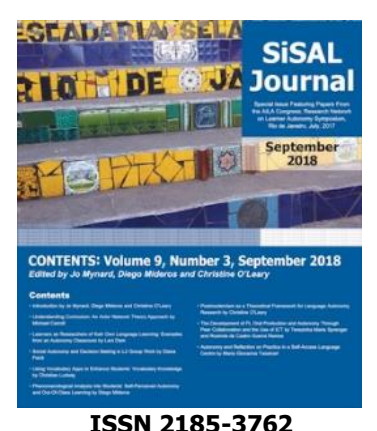

Studies in Self-Access Learning Journal

http://sisaljournal.org

\title{
Social Autonomy and Decision Making in L2 Group Work
}

ISSN 2185-3762

Diana Feick, University of Auckland, New Zealand

Corresponding author: diana.feick@auckland.ac.nz

Publication date: September, 2018.

\section{To cite this article}

Feick, D. (2018). Social autonomy and decision making in L2 group work. Studies in Self-Access Learning Journal, 9(3), 280-305.

\section{To link to this article}

http://sisaljournal.org/archives/sep18/feick

This article may be used for research, teaching and private study purposes. Please contact the author for permission to re-print elsewhere.

Scroll down for article. 


\title{
Social Autonomy and Decision Making in L2 Group Work
}

\author{
Diana Feick, University of Auckland, New Zealand
}

\begin{abstract}
This article presents an investigation into the socio-interactional nature of learner autonomy in language learning groups. The study is situated in the context of a mobile phone video project with 13 Mexican adult learners of German as a foreign language (GFL). The aim was to examine autonomy, heteronomy and participation in L2 classroom negotiations in a group work situation. These constructs have been shown to be highly influential in second language learning in an institutional context (Little, 2000; O'Leary, 2014; Schmenk, 2008; Thornbury, 2011). Decision-making episodes of three project groups were examined from an interactional, participational and sequential point of view. The analysis offered both an etic and an emic perspective on L2-group negotiation processes and allowed for the detailed reconstruction of collective and cooperative participation mechanisms. It unveiled a strong link between individual interaction styles, different types of participation, group discourse patterns and the display of group autonomy and/or personal autonomy. These findings inform an empirically grounded theoretical model of group autonomy in the L2 classroom, which will be introduced in this paper.
\end{abstract}

Keywords: Learner autonomy, project work, group decision-making, group autonomy, German as a Foreign Language

Social learning, like group or project work, in foreign language classes offers learning opportunities through interaction with more capable peers (Wygotski, 1934). It mostly takes place in language learning institutions, courses and classrooms. Autonomous (language) learning, on the other hand, has been largely conceptualized as an individual process focusing on individual interests, preferences, responsibility and agency (Benson, 2001; Europarat /European Council, 2001; Holec, 1981). It can be implemented through self-access centers, language advising or CALL, which mostly limit autonomous learning to outside classroom learning settings. However, learner autonomy entails more than this individualistic perspective, especially when it is regarded from a socio-cultural perspective of language learning. Within this framework, autonomous learning is a constructed, situated and dynamic relationship between learners and their sociocultural context (Benson \& Cooker, 2013; Little, 2000). The placement of autonomy within this learning theory is in need of more empirical foundation and 
SiSAL Journal Vol. 9, No. 2, September 2018, 280-305.

(re)connection to specific language teaching and learning contexts. Studies on learner autonomy from a socio-cultural perspective have so far not looked at social language learning and how it evolves within group or project work. Thus, the aim of this study was to provide an empirically based reconceptualization of learner autonomy as a socio-interactional construct that recognizes the coexistence of autonomy and heteronomy in institutional language learning contexts. Schmenk (2008) defines heteronomy in language learning as carrying out goals and tasks imposed by others but not the learner. This study refers to heteronomy also as third party determination.

A broader conception of autonomy as social autonomy must first be established, where this social aspect is understood as a social practice and not merely as a cooperative learning strategy of an individual learner. Social autonomy is understood in this study as interdependence (Little, 2000), collective responsibility (Simmons \& Wheeler, 1995; Little, 2000) and shared control over learning that is reached through negotiation (Holliday, 2003; Schmenk, 2008; Thornbury, 2011).

In this study, the autonomy of the group, or group autonomy, was regarded as a form of social autonomy. However, group autonomy is not the sum of individual autonomies of group members but the autonomy of a group as a whole. Its interrelationship with personal autonomy and heteronomy is illustrated in Figure 1.

personal autonomy

group autonomy

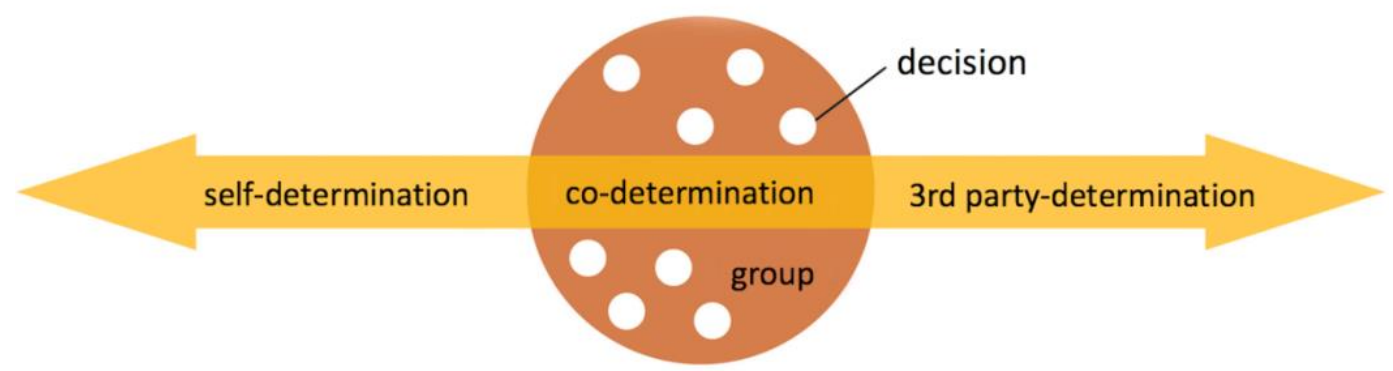

Figure 1. Group autonomy and co-determination (translated from Feick, 2016, p. 74)

Autonomous learning as social practice is anchored in group processes as group autonomy. It is placed on a continuum between personal autonomy and 
SiSAL Journal Vol. 9, No. 2, September 2018, 280-305.

heteronomy. Heteronomy in this study is understood as third party-determination and occurs when parties other than the learner or a learner group, e.g. a teacher, an institution, a curriculum or the used teaching resources reduce the scope of possible individual choices about contents and ways of learning. Therefore, group autonomy develops through co-determination in group decision-making discourse. Given this, group decisions are the central indicator of group autonomy if they are reached through consensus-based co-determination.

Co-determination is linked to the concept of legitimate peripheral participation (Lave \& Wenger, 1991), when a novice participates peripherally in a community of practice and gains competence until he or she fully participates in this community as an expert.

Group decisions are characterized in this study from a linguistic perspective as the collective choice of one out of at least two alternative future actions and include either carrying out that action or forming an intention to make that action happen (Gunnarsson, 2006). Gunnarsson (2006) describes group decision-making interaction using an activity-based communication analysis framework (Allwood, 1993). According to Gunnarsson (2006, p. 141) group decision-making is characterized by the activity type of "arguing" with its central communicative acts of "proposing" and "accepting", followed by other communicative acts such as "modifying proposals", "disagreeing with a claim" or "eliciting information".

This framework can link the findings from research on linguistic group interaction and language learning. Findings from L2 interaction research confirm that there is a positive influence of peer or group interaction on the development of communicative competence (in GFL, e.g. Eckerth, 2003; Legenhausen, 2010). Furthermore, Storch (2001, 2002a, 2002b) describes patterns of dyadic peer interaction that are conducive to language learning: the expert-novice and the collaborative pattern. Storch (2002, p. 129) characterizes the former pattern as moderate to low equality and moderate to high mutuality meaning that the expert encourages the novice to participate in the task. Both patterns are characterized by equality in sharing control over the direction of an activity and by mutuality. Here, mutuality is understood as a high level of interactional engagement with contributions of peers (e.g. reciprocal feedback or sharing of ideas). These patterns have also been proven to be conducive to language learning during 
SiSAL Journal Vol. 9, No. 2, September 2018, 280-305.

collaborative online writing tasks in groups (Li \& Zhu, 2017) patterns of group interaction in an offline language learning context have not been investigated as yet.

The present study was placed in the context of a GFL learning project. This teaching method forms part of the open learning approach due to its high degree of self-determination, and therefore, contains the highest potential for developing group autonomy. The main research question that guided the study was: what is the potential of social autonomy in project work in GFL?

This question was divided into the following sub-questions:

1. What do decision-making processes of polyadic interaction look like within in-class meetings of a mobile phone project?

2. Which forms of (co-)determination are displayed within these group decision-making processes?

3. How are these interaction processes perceived retrospectively by single group members?

The following section presents the research design of the study, and is followed by sections on the main research findings, a discussion and conclusion.

\section{The study}

The investigation was an explorative-interpretative classroom interaction study. It was conducted in 2010 in the context of a mobile phone video project with 13 Mexican adult learners of GFL (Feick, 2014). Their proficiency was at least at the B1 level according to the Common European Framework of Reference, and they were taking German as an elective course at the university (groups 1 and 2) or attending a course at a private language school (group 3). As part of these classes a mobile phone video project was carried out over five weeks. The groups had between three and five members. The project aimed at the production of short video clips in German in order to foster the students' communicative competence. Therefore, the use of the target language during the project was encouraged. The composition of groups and the choice of video genre were left to the students, therefore, the groups were formed according to their interest in a specific genre. This resulted in the production of a video survey, a short fictional clip and a video report. The project work took place during the two 
SiSAL Journal Vol. 9, No. 2, September 2018, 280-305.

two-hour classes per week and also outside the classroom. It included the typical steps of video production: topic choice, script writing, preproduction, shooting and postproduction (see project concept in Appendix A). Some of the participants had some previous knowledge of certain aspects of film-production.

\section{Data collection and corpus}

The study was designed as a between-method-triangulation (Denzin, 1978) integrating an emic perspective (from the participant's point of view) and an etic perspective (from the observer's point of view) for gaining a holistic view of group decision-making processes. Therefore, video ethnography (method 1) (Knoblauch, 2006) was combined with retrospection (method 2) (Dörnyei, 2007). To answer research questions 1 and 2 (etic perspective) the in-class group meetings were video recorded. The first 15-45 minutes of these recordings were used to trigger individual video stimulated recall (VSR) (see instructions in Appendix B). Video-stimulated recall is a form of "loud remembrance", prompted by a video recording. Its purpose is to elicit unfiltered verbal recollections (cognitions, emotions, and motives) of mental or (inter)actional actions from the long term memory (Knorr \& Schramm, 2012, p. 185). This method allows to investigate the emic perspective of the group interaction and was applied to answer research question 3.

The VSR sessions were carried out twice - once in the planning phase of the project and once during the project evaluation. This method aimed at collecting data of the group members' remembered cognitions and emotions during the group negotiations and acquiring data of retrospective explanations of the individual interactional behavior (Feick, 2012). The data sampling strategy was event based, meaning that data was collected from project phases with a high decision making density: the project planning and the project evaluation. The resulting data corpus consisted of 10:20 hours of video data. For the VSR four hours of interaction data were chosen from the corpus and produced another 11:54 hours of retrospective data (loud remembrances).

\section{Data analysis and findings}

Data analysis consisted of three stages. In the first stage, group negotiation and retrospective data were analyzed for the pattern of group interaction. In the 
second stage, the same data were analyzed from a participational point of view, looking at the impact of the individual contributions to the outcome of a decisionmaking episode in order to reconstruct forms of co-determination and to identify the group members' self-perception of these processes. And thirdly, a sequential analysis of group decision episodes was carried out in order to determine the decision-making modes of each group, regarding them as three different cases. Data analysis was carried out with the qualitative data analysis software MAXQDA and included 15 decision-making episodes which were examined using the stage model of empirically grounded typology (Kluge, 1999). This entails four stages of analysis: (1) elaboration of relevant dimensions for comparison, (2) grouping of cases and analysis of empirical regularities, (3) analysis of content-related connections and formation of types and, (4) characterization of the formed types. It aimed to classify interaction styles and participation types through grouping the data according to similarities and differences using comparative and contrasting analysis. This cyclical process leads to a characterization of the encountered types and is the pre stage of formulating a hypothesis about the compared dimensions.

\section{Stage 1 of data analysis: Interaction analysis}

The interaction data were transcribed in the HIAT system ${ }^{1}$ with the software EXMARaLDA Partitur Editor (see Appendix C). The retrospective data were integrated in these transcripts, so that the recalled memories were displayed with the segment of interaction they were referring to. These transcripts include suprasegmental features and multimodal aspects such as eye communication, gaze, head movements, gestures, facial expressions, posture and setting. The deductive-inductive interaction analysis used the (sub-)categories of peer interaction developed by Storch (2001, 2002a, 2002b), for example requests, questions, simultaneous talk, repetitions, co-construction, and collective scaffolding. They were adapted and extended through categories like securing understanding (Kameyama, 2004), negotiation of meaning (Long, 1996),

\footnotetext{
${ }^{1}$ HIAT is the acronym for "Halbinterpretative Arbeitstranskriptionen" (SemiInterpretative Working Transcriptions), which provides a 'literary transcription' and is used predominantly in functional-pragmatic discourse analysis (Rehbein, Schmidt, Meyer, Watzke \& Herkenrath, 2004).
} 
SiSAL Journal Vol. 9, No. 2, September 2018, 280-305.

justification (Ehlich \& Rehbein, 1986), explanation (Hohenstein, 2006) and different subcategories of nonverbal behavior (see complete overview in Feick, 2016).

The following example illustrates the interaction analysis (detailed description in Feick, 2016). The participants have been given pseudonyms. JUAN negotiates with his peers RINA, LARA and EMMA the decision subject "work organization", which relates to the decision-making episode 15 "closing remarks of the video survey". 


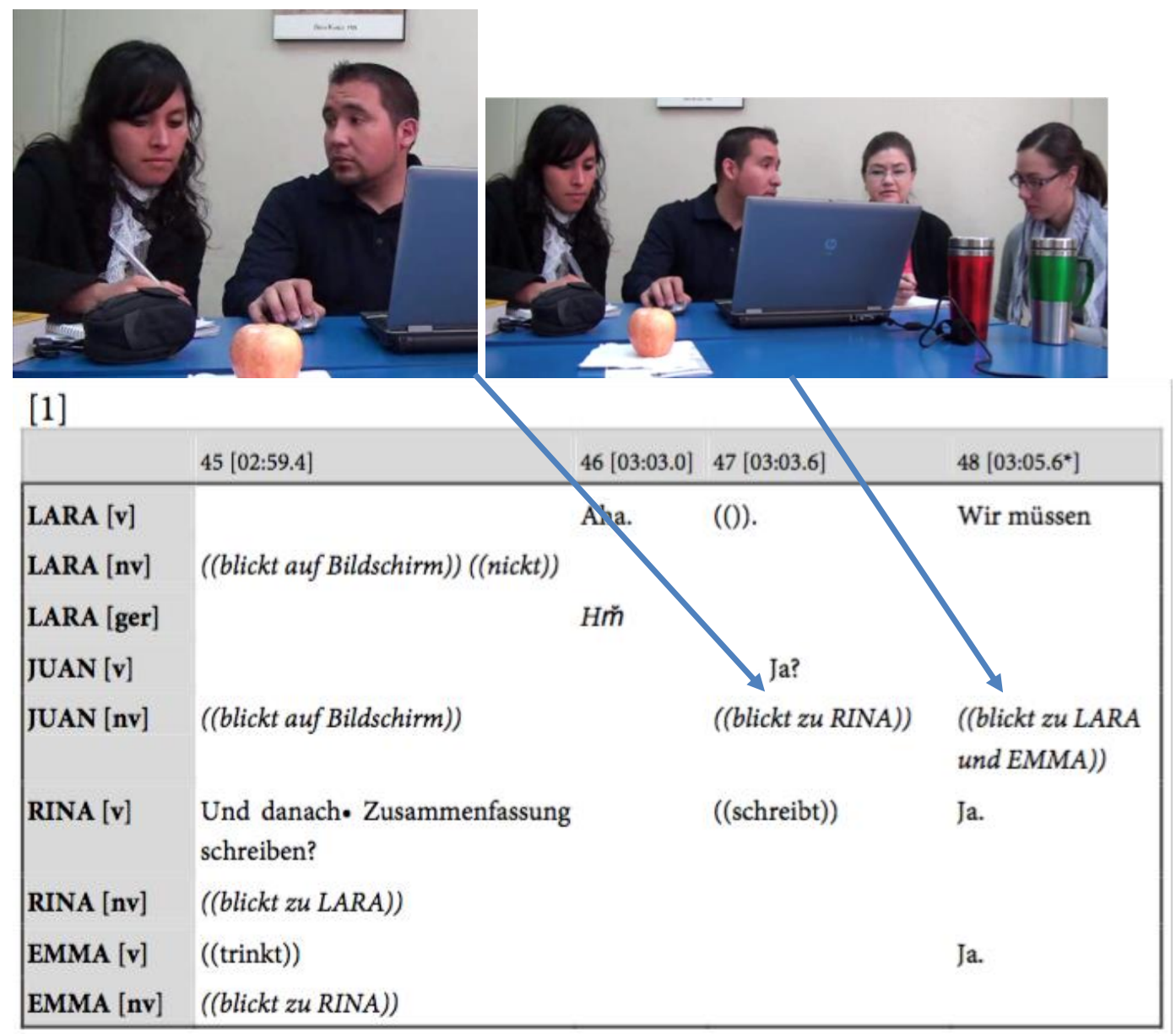

[2]

\begin{tabular}{|c|c|c|}
\hline &. & $49[03: 10.1]$ \\
\hline LARA [sup] & & ((lacht)) \\
\hline LARA [v] & - die Filme sehen. & \\
\hline LARA [nv] & ((blickt zu EMMA)) & \\
\hline JUAN [v] & (Gut?) Okay. & Filme sehen. \\
\hline JUAN [nv] & $(($ nickt $))$ & $(($ blickt auf Bildschirm $)) \quad(($ startet Video $))$ \\
\hline JUAN [VLE-Sp] & & $\begin{array}{l}\text { Por la misma vez, nes/ más bien díganme qué } \\
\text { quieren qué haga y lo hago con todo el gusto, pero } \\
\text { mis neuronas no estaban dando para mucho. }\end{array}$ \\
\hline JUAN [VLE-Dt] & & $\begin{array}{l}\text { Noch einmal, sagt mir lieber, was ihr wollt, was ich } \\
\text { tun soll und ich mache es mit dem größten Ver- } \\
\text { gnügen, aber meine Neuronen taugten noch nicht } \\
\text { viel. }\end{array}$ \\
\hline
\end{tabular}

Transcript 1: German transcript extract of decision episode 15: summary (Feick, 2016: 167). Translation is provided within the next paragraph.

In segment 45, JUAN's attention is focused on the computer screen, because he is the group's operator of that device. Simultaneously, RINA initiates the decision-making about the first decision subject of episode 15 , preceded by a 
SiSAL Journal Vol. 9, No. 2, September 2018, 280-305.

3-minute negotiation process. She therefore uses the decision question about how to proceed: "And then writing the summary?" ("Und danach Zusammenfassung schreiben?") (seg. 45). LARA responds to this in segment 46 with the affirmative interjection "Aha." (German: "Hั̆").

JUAN then directs himself towards RINA through a verbal confirmation check (request: "Yes?” (“Ja?”)) and through the nonverbal change of his viewing direction (see left still). She approves the planned procedure verbally with "Yes." (“Ja.") (seg. 48) while writing something. Then JUAN indicates with his 180 degree head movement (see right still) that he also expects feedback from the two other group members. Concurrently EMMA affirms with "Yes.” (“Ja.”). So all group members agree with RINA's proposal about the timing of the writing of the summary. Simultaneously, LARA expresses the call for action that arises from the decision just made: "We have to watch the films." ("Wir müssen die Filme sehen.”) (seg. 48). With this she identifies the necessary condition and next action step in order to carry out the group decision. JUAN affirms this nonverbally by nodding and verbally with the utterance "Okay." (seg. 48). He then repeats LARA's call for action "Watch the films." ("Filme sehen.”) (seg. 49). Finally, in segment 50, he carries out the group decision by starting the video on the computer.

In the VSR account ${ }^{2}$, JUAN stresses his agreement with the other group members, and his willingness to receive instructions from the others and to carry out these instructions. This implies him giving over his decision-making agency. His interactional engagement in this case is directed to the implementation of a decision rather than to the verbal participation in choosing one of the decision options.

The first partial result of the analysis are four styles of interaction in

2

Translation of VSR (by the author): "Once again, better tell me what you want me to do and I will do it with great pleasure, but my neurons were not working yet." 
SiSAL Journal Vol. 9, No. 2, September 2018, 280-305.

groups (L stands for learner and the size of the circles indicates the level of dominance):

- dominant collaboration

- passive collaboration

- dominant non-collaboration

- passive non-collaboration

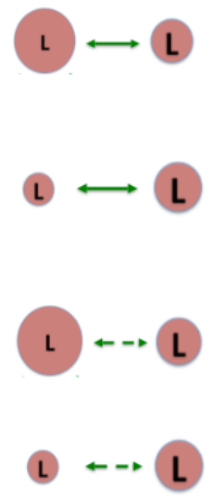

The aspect of dominance or passivity shows an individual's degree of participation in the interaction (high vs. low, see Storch, 2001). The collaboration feature refers to the degree of equality (control over an activity) and mutuality (level of engagement with each other's contribution) (Storch, 2001; Damon \& Phelps, 1989). The style of dominant or passive collaboration is therefore characterized by co-construction, collective scaffolding and linguistic activities like requests, questions, feedback, repetitions, completion of utterances, etc. On a multimodal level active eye communication, head movements, gestures, mimic and posture lead to equality and mutuality. From the analysis, Juan represents an example of passive collaboration. The dominant or passive style of noncollaboration is represented by an unequal distribution of turns, little or no verbal engagement with peer contributions, little or no co-construction, and a high rate of communicative activities like counter-suggestions, rejections, contradictions, few or no requests or questions, and nonsense contributions. On a multimodal level, representatives of this style show little or no eye contact and an opposing or static facial expressions, gesture and posture.

\section{Stage 2 of data analysis: Participation analysis}

In a second stage data were analyzed from a participational perspective to explore the influence of each group member on identified decision results or decision-making episodes (detailed description in Feick, 2016). Participation therefore was regarded as the active performance of co-determination where the influence on the decision-making discourse is displayed through: 
SiSAL Journal Vol. 9, No. 2, September 2018, 280-305.

- means of meta-communicative discourse regulation (e.g. concluding or summarizing the structure, organizing and focusing the negotiation process),

- the development, explanation, adaptation and evaluation of decision options, and

- the participation in carrying out decisions.

This aspect was complemented with the feature of cooperation, which is the mentally shared group goal orientation (Fiehler, 1978). Cooperation is displayed in the retrospective data as mental anticipation of carrying out the action plan, an orientation towards the action plan and the will to pursue a group goal.

The following example illustrates the participation analysis (detailed description in Feick, 2016). The participant with the pseudonym RINA negotiates with her peers JUAN, LARA, SONJA and EMMA the decision subject "number of interview partners" related to the decision-making episode 13 "interview partners" 
SiSAL Journal Vol. 9, No. 2, September 2018, 280-305.

\begin{tabular}{|llll|} 
& & $49[03: 46.1]$ & $50[03: 49.1]$ \\
\hline LARA [v] & (Hm̌.) & & \\
JUAN [v] & Hm̌hm̌. & & \\
JUAN [nv] & nickt & & $((1 \mathrm{~s}))$. Hm̃. Alle. \\
SONJA [v] & & \\
EMMA [v] & Das ist eine gute Frage. & Wie viele Leute möchten wir fragen? & \\
\hline
\end{tabular}

[5]

\begin{tabular}{|c|c|c|c|}
\hline & $51[03: 52.2]$ & & $52[03: 56.4]$ \\
\hline LARA [v] & $(0)$ & & (Das ist viel.) \\
\hline SONJA $[\mathbf{v}]$ & Hm̌. & & (Wie viel?) \\
\hline RINA [v] & & Oder meisten. & Aber, aber filmen nur zehn oder fünfzehn. \\
\hline EMMA [v] & Alle, alle Schule? & & Okay. \\
\hline
\end{tabular}

[6]

\begin{tabular}{|c|c|c|}
\hline & $53[04: 01.4]$ & $54[04: 04.8]$ \\
\hline LARA $[\mathbf{v}]$ & $\mathrm{Ja}$, weil wir müssen fünf Minuten maximal & haben. Die Zeit. \\
\hline JUAN [v] & Hm̌. & Is okay. \\
\hline SONJA [v] & & Fünf Minuten? Ja. \\
\hline RINA [v] & Ja. & \\
\hline EMMA [v] & & $(0)$ \\
\hline
\end{tabular}

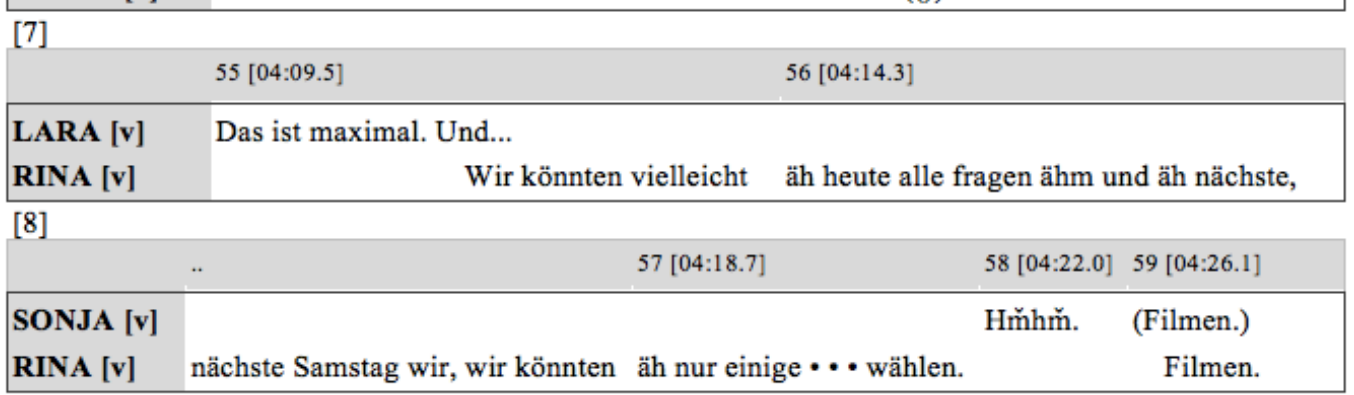

Transcript 2: German transcript extract of decision episode 13: development of a decision alternative (Feick, 2016: 207). Translation is provided within the next paragraph.

EMMA initiates the negotiation on the topic in segment 49 with the decision question "How many people would we like to ask?" ("Wie viele Leute möchten wir fragen?”). SONJA proposes “All.” (“Alle.”) (seg. 50). EMMA questions this: “All, all school?" (“Alle, alle Schule?”) (seg. 51), so that RINA modifies the suggestion: "Or most." (“Oder meisten.") (seg. 52.) and adds in segment 52: "But, but filming only ten or fifteen” (“Aber, aber filmen nur zehn oder fünfzehn.”). LARA supporting this suggestion in seg. 53: "Yes, because we must have five minutes maximum. The time." (“Ja, weil wir müssen fünf Minuten maximal haben. Die Zeit.") agrees with her as do JUAN (seg. 53: "Hm. ”, Seg. 54: “Is okay. ”), and SONJA (seg. 54: "Five minutes? Yes. ”) (“Fünf Minuten? Ja."). In segment 55 - 57 RINA takes over and summarizes the decision alternative in favor "We could maybe ask all today and next, next Saturday we, 
SiSAL Journal Vol. 9, No. 2, September 2018, 280-305.

we could only choose some. Film them." ("Wir könnten vielleicht heute alle fragen und nächste, nächste Samstag wir, wir könnten nur einige wählen.”). When modifying this option she also consolidates the decision as she gets affirmative feedback from the group during and after her utterance. RINA participates actively in this episode (cooperative participation) to develop a decision alternative using modifications and repetitions that have a central impact on the final result of the negotiation process. The decision is made implicitly since all group members agree (partially nonverbal) to RINA's proposal and the next episode starts immediately after that with the discussion of the decision object for the interview questions.

Using a typological analysis approach (Kluge, 1999) four types of participation were reconstructed:

- cooperative participation

- non-cooperative participation

- cooperative non-participation

- selective participation

The cooperative participation type actively performs his/her influence on the decision-making process using the above mentioned (meta-)communicative means and mentally shares the group goal in all phases of a decision-making episode (as in the case of RINA). The non-cooperative participation type does not share the group negotiation goal, so he/she uses his/her co-determination to delay or hinder the pursuit of the group goal. The cooperative non-participation type is characterized by the lack of a will to co-determination or by little influence on the negotiation discourse, but this type generally shares the reaching of the group goal. Finally, the selective participation type shows that the borders of each type are fluid. It is characterized by alternating phases of cooperative participation and cooperative non-participation. Regarding the interactional side of participation, it must be stated that an interaction style is the discursive display of a type of participation. Group members can interact without participating (in the sense of co-determination), but not the other way around.

\section{Stage 3 of data analysis: Sequential discourse analysis}


SiSAL Journal Vol. 9, No. 2, September 2018, 280-305.

The third stage of analysis brought together the results of stage 1 and 2 and observed them from a case study perspective in order to explore the individual interaction styles and participation types in terms of their impact on the (form of the) decision-making process of each of the three groups. Therefore, a sequential discourse analysis was carried out, which consisted of color-coding the steps of linguistic actions for each episode. These actions included the presentation of a problem $(\mathrm{P})$, suggestions $(\mathrm{V})$, modification $(\mathrm{Va}(\mathrm{P}))$, explanation (E), justification (B), counter-arguments (GA), agreements $(\mathrm{Z}(\mathrm{V}))$ and the act of decision-making $(\mathrm{EH})$. The following example illustrates the sequential discourse analysis (detailed description in Feick 2016).

Entscheidungsepisode „Filmthema“ (G3-1a, 00:28'-15:10')

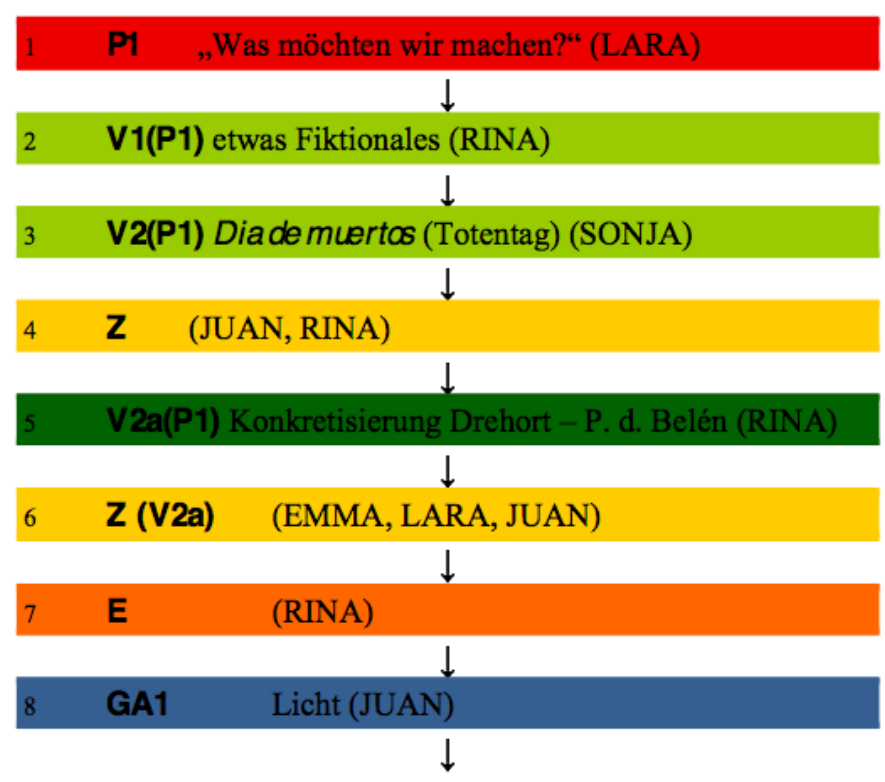

Figure 2. Example sequential discourse analysis

The decision-making negotiation consists of 36 action steps, of which the first eight are represented in figure 2 . The episode starts with the expression of a problem (P1) when LARA asks what kind of film the group wants to do ("Was möchten wir machen?"). RINA utters the first suggestion V1(P1) proposing something fictional. Then SONJA makes a second suggestion V2 (P1) to do something about the Day of the Dead. RINA and JUAN express their agreement to this suggestion in action step 4 . This is followed by a modification of this suggestion V2a (P1) when RINA proposes to shoot at one specific cemetery 
SiSAL Journal Vol. 9, No. 2, September 2018, 280-305.

(Panteón de Belén). In action step 6 EMMA, LARA and JUAN agree to this modification of suggestion V2. Thereupon RINA gives an explanation (E) for her modification by referring to guided tours that are offered at this cemetery. JUAN then utters a counter argument (GA1), that the tours cannot be recorded if they take place at noon because of lighting conditions. The final decision-making action (EH) is carried out in action steps 33 - 35 by voting for one of the discussed options - the group chooses to do a video survey about reasons for learning German.

The form and order of the action steps in each episode were compared both to those of the other episodes within the group and across the groups and allowed for the reconstruction of three group-specific discourse modes:

- "one for all-all for one" - the convergent group decision-making discourse (group 3)

- "two against one" - the discursive alliance through delegitimation and exclusion (group 1)

- “one against all" - the divergent group decision-making discourse mode (group 2)

The case of a prototypical three-member-group that applies for the convergent group decision-making discourse mode is illustrated in Figure 3. L stands for learner and D for decision.

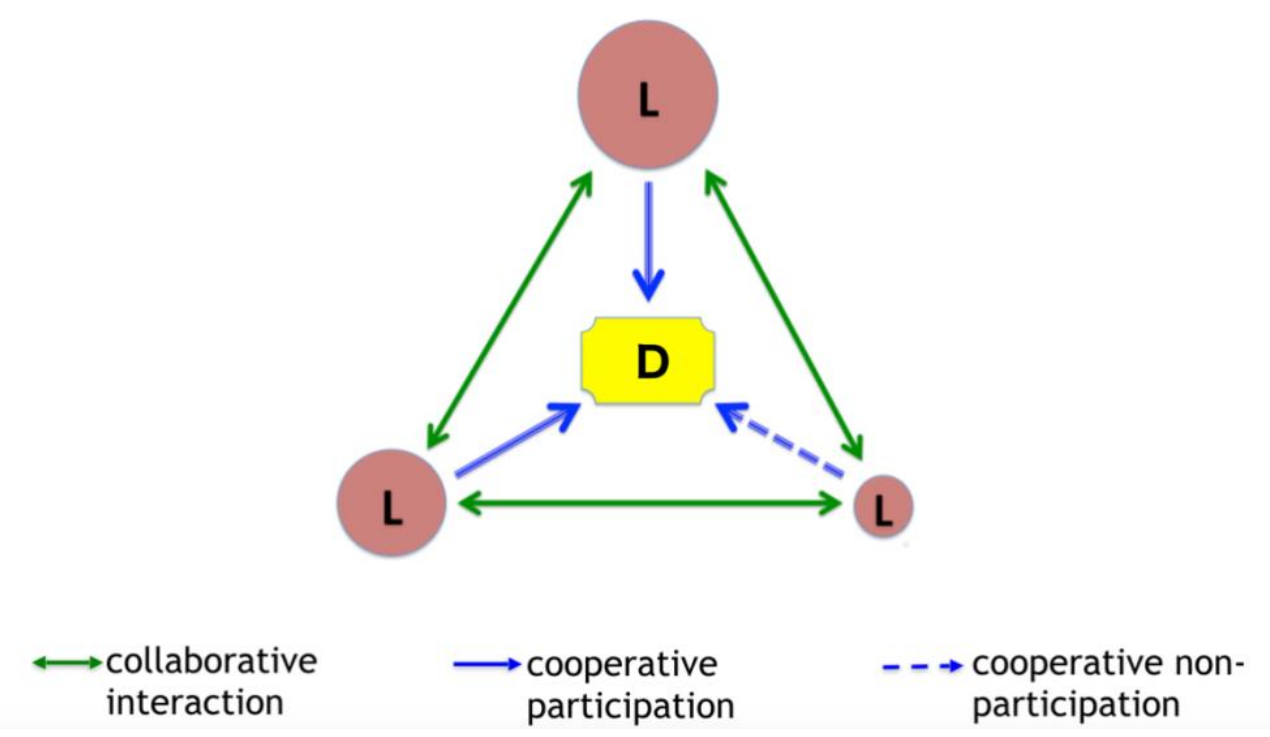

Figure 3. Convergent group decision-making discourse mode (translated from Feick 2016, p. 333) 
SiSAL Journal Vol. 9, No. 2, September 2018, 280-305.

Convergence is a shared discursive system of evaluation (Grießhaber, 1987). This discourse mode is determined by cooperative participation and collaborative interaction (dominant (big circle) or passive (small circle)) and a (retrospectively expressed) positive self-perception of all group members. It leads to consensus-based and co-determination-based group decisions. In this mode the type of cooperative non-participation type can occur, but it needs to be implemented through the interactional style of dominant or passive collaboration to facilitate group decisions. This group member does not actively influence the decision-making process, but he/she mentally shares the group goal.

The second discourse mode is called "discursive alliance" and was found in group 1. It is illustrated in Figure 4. While two group members form an alliance and interact collaboratively with each other, they interact noncollaboratively with the third member. Thus, only two group members participate in the decision-making, while the third person maintains a state of nonparticipation. This is caused, as retrospective data shows, by mental delegitimation (due to prior incidents in the project work) and interactional exclusion - so the third member is prevented interactively from influencing the decision-making process. This exclusion happens on purpose and is due to the mental state of the delegitimizing peers, who do not give the right of codetermination to the group member and therefore exclude him/her from decisionmaking. In these discourses decisions are made individually or between the two allied group members.
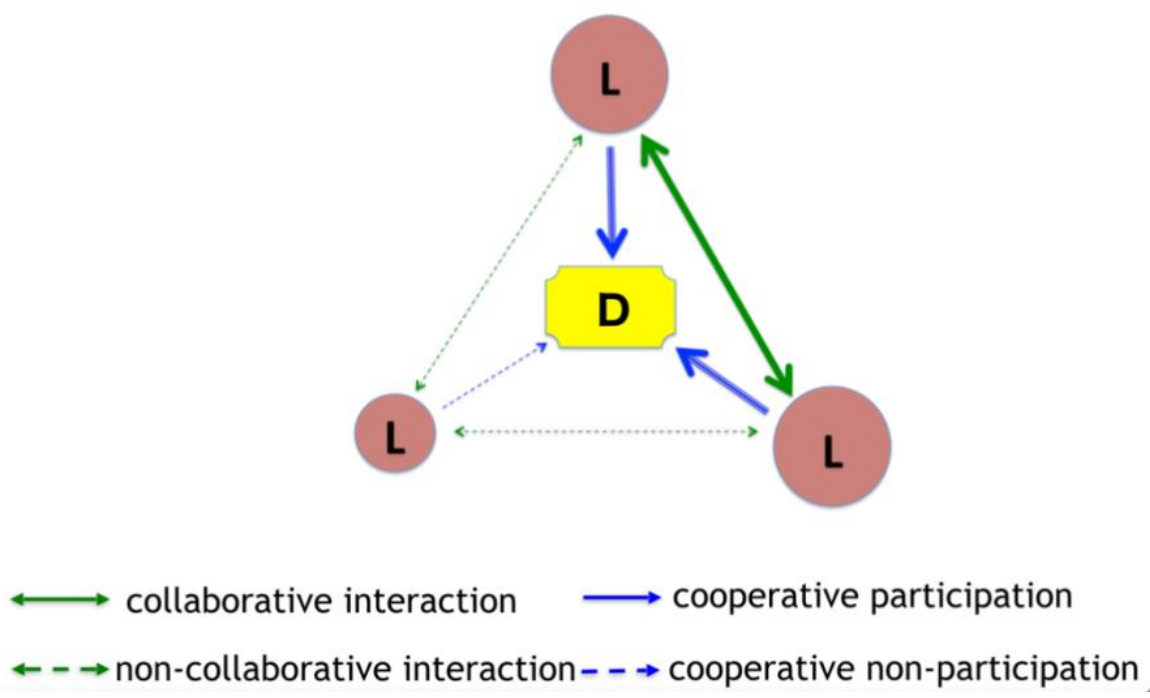

Figure 4. Discursive alliance (translated from Feick 2016, p. 335). 
SiSAL Journal Vol. 9, No. 2, September 2018, 280-305.

The third discourse mode is the divergent discourse, where group members do not display a common discursive evaluation system. Within this mode group decisions are not reached or are only made after several negotiation rounds or self-determined individual decisions are made.

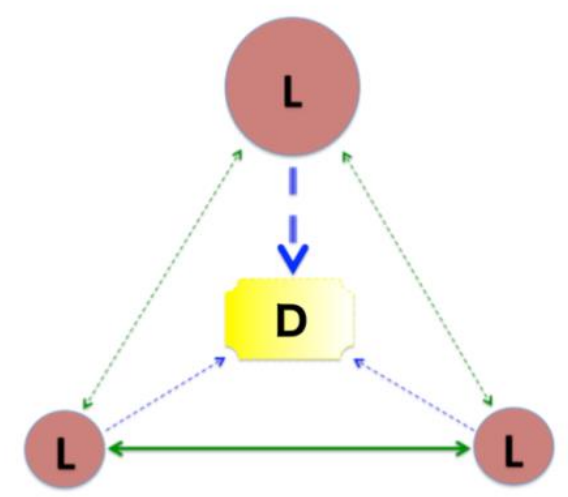

\section{$\longleftrightarrow$ collaborative interaction $\quad \longrightarrow$ non-cooperative participation} $\leftrightarrow-\rightarrow$ non-collaborative interaction $-\rightarrow$ cooperative non-participation

Figure 5. Divergent group decision-making discourse mode (translated from Feick 2016, p. 336)

This is caused by an interactively dominant, but non-collaborative group member, who participated non-cooperatively in the negotiation process. If other group members interact collaboratively they do not exert influence on the process because of the dominant, non-collaborative interaction style of the noncooperative group member.

\section{Summary and Discussion of Results}

The aim of the study was to explore autonomy, heteronomy and participation in L2 interactions looking at possibilities and limitations of self- and co-determination of individual group members while negotiating decisions during a language learning video project. The results show a complex and dynamic relationship of self-, third party- and co-determination in group work which are illustrated in Figure 6.

The reconstructed decision-making discourse modes of the three groups reveal two types of autonomy: group autonomy and personal autonomy. Group autonomy unfolds when group decisions are made in a convergent discourse mode (left side of the figure, left inner circle). Divergent discourse modes lead to 
individual or no decisions and display personal autonomy (right side of the figure, right inner circle).

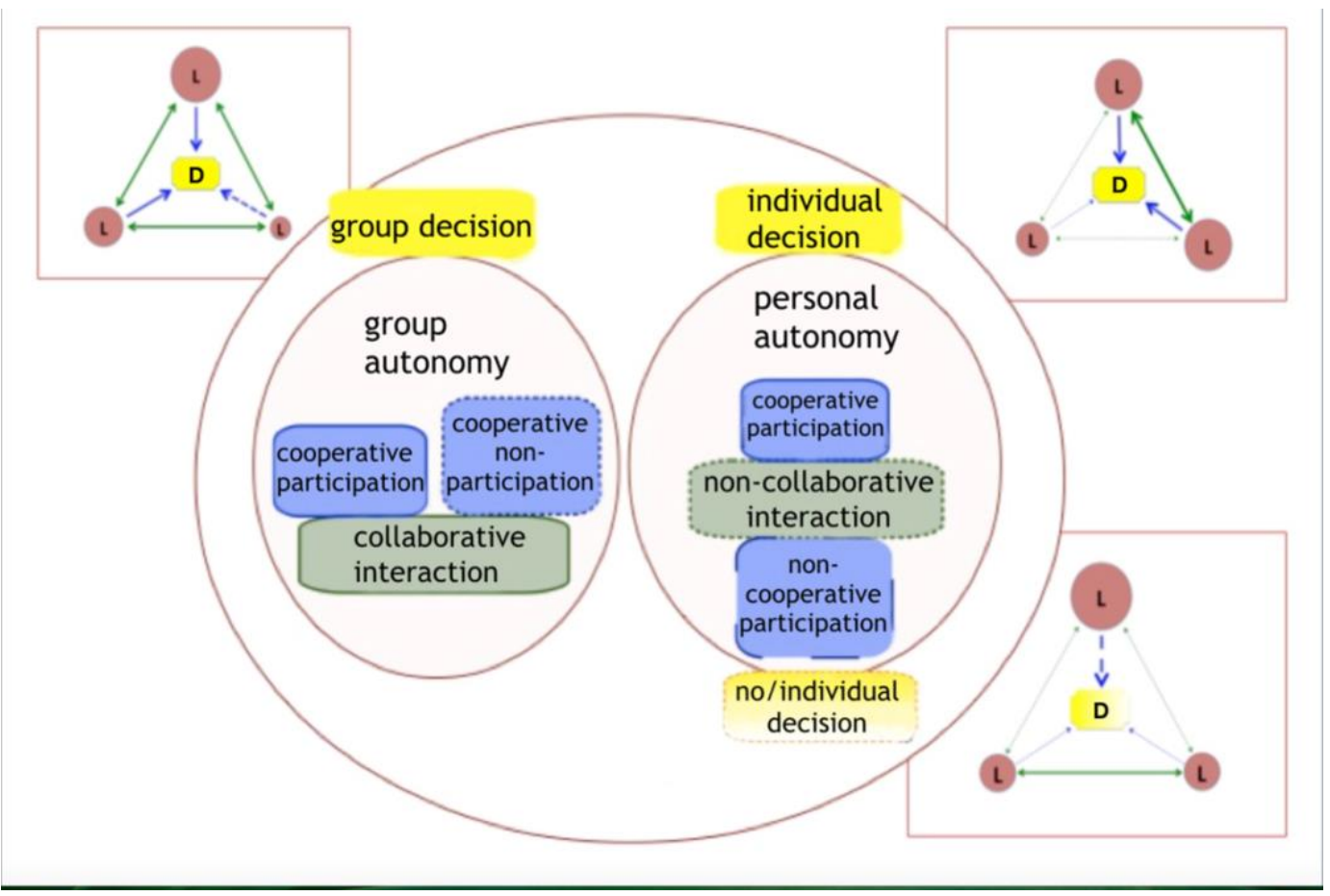

Figure 6. Group autonomy in decision-making discourse (Feick 2016, p. 332)

Furthermore, the results of the study lead to the following definition of group autonomy (translated from Feick 2016, p. 343):

The autonomy of a learner group unfolds within a group interaction process when group decisions are mainly negotiated in a convergent discourse mode. A convergent discourse mode is characterized by cooperative participation and collaborative interaction. Cooperative participation is represented by group goal sharing co-determination and is displayed by collaborative interaction.

Taking these findings into consideration, their relevance for the potential of autonomy in group decisions needs to be questioned. The analysis of group decision-making processes in GFL has shown something classroom researchers and teachers may already suspect: not all groups work collaboratively and cooperatively when they negotiate decisions during their task or project work. The study found that interdependence, collective responsibility and shared control in learner groups unfolds through collaborative co-determination and (the will for) participation in group decision-making. A convergent group discourse which is characterized by collaborative interaction and cooperative participation seems to be more favorable for creating group autonomy. It is important to state that co- 
SiSAL Journal Vol. 9, No. 2, September 2018, 280-305.

determination also can be exercised with a temporary postponement of individual agency which is represented by the type of cooperative non-participation type and carried out through passive collaboration. Thus in this constellation especially but also in other group decision-making modes - multimodal communication proved to be a regulator of participation processes. It is also important to note that the reconstructed interaction styles and participation types are not static patterns that group members maintain consistently during the whole project but are rather flexible and individually adapted throughout the whole negotiation process. They also do not necessarily reflect expected patterns from typical group work roles like presenter, manager, checker, time keeper or recorder that were introduced and assigned in each group at the beginning of the project.

The study found that group autonomy, as distinct from personal autonomy could be empirically described as a discrete form of learner autonomy. As the data revealed, group autonomy is generated only within discursive negotiation processes, while individual autonomy is rather seen as a mental disposition of a learner (e.g. Benson 2001). Group autonomy entails both interactional and participational behavior and a mental disposition of group goal orientation (see also Li \& Zhu 2017). Therefore, the reconstructed participation types include the retrospective accounts of remembered cognitions and emotions during the negotiation process.

The findings presented are limited to socio-culturally homogenous learner groups and the discussion does not consider gender, age or other group dynamic aspects that may influence group decision-making.

\section{Conclusion}

Group decision-making discourses in a foreign language learning setting can be characterized as complex interrelationships of interactional activity, passivity and dominance, mutual engagement and equal participation. Therefore a convergent group decision-making discourse can be seen as a key indicator for group autonomy. Group autonomy is understood as only one form of social autonomy. Other dimensions of group autonomy related to group characteristics and contextual factors are yet to be explored. 
SiSAL Journal Vol. 9, No. 2, September 2018, 280-305.

Observing the implications of this study for language learning and teaching, there are some recommendations for action in institutional course contexts or in social learning settings in order to activate the potentials of group autonomy (Feick, 2017). Teachers together with their learners could analyze interactional behavior during group work. This analysis aims at raising awareness about the different interaction styles and participation types and their effect on decision-making, and in the broader sense, on group autonomy. The analysis can be carried out in the group or individually and are ideally based on video recordings of the group work in question. Video-based stimulated recall can be used as a method to initiate these processes. Learners could recognize and reflect upon their interaction style and participational behavior in the group.

Furthermore, to foster group autonomy and improve group work, training in interactional skills and techniques for group negotiation and decision-making in the target language are recommended.

A future direction of research could be the exploration of the effect of convergent group discourse on (social) language learning. Inquiries might also investigate group autonomy from the perspective of complex dynamic systems theory, which could take aspects like culture, gender, age group roles and power relationships within foreign language group interaction processes more into consideration.

\section{Notes on the contributor}

Dr Diana Feick is a Senior Lecturer in German and Applied Linguistics at the University of Auckland. She holds a PhD in German as a foreign language from the University of Leipzig, Germany. So far, her vocation as a German teacher trainer has taken her to countries like Benin, Chile, Colombia, Egypt, Greece, Mexico, Spain, Togo, the UK and Vietnam. Diana's research interests are digital media, learner autonomy, and multimodal foreign language interaction.

\section{References}

Allwood, J. (1993). Language, communication and social activity - Towards an analysis of the linguistic communicative aspects of social activities. In K. Junefelt (Ed.), Special session on activity theory, Proceedings of the XIVth Scandinavian conference of linguistics and the VIIIth conference of 
SiSAL Journal Vol. 9, No. 2, September 2018, 280-305.

Nordic and general linguistics, August 16-21, 1993. In Gothenburg papers in theoretical linguistics 73. Department of Linguistics, Göteborg University, Sweden.

Benson, P. (2001). Teaching and researching autonomy in language learning. Harlow, UK: Longman.

Benson, P. \& Cooker, L. (2013). The social and the individual in applied linguistics research. In P. Benson \& L. Cooker (Eds.), The applied linguistic individual: Sociocultural approaches to identity, agency and autonomy (pp. 1-16). London, UK: Equinox.

Damon, W., \& Phelps, E. (1989). Strategic uses of peer learning in children's education. In T. Berndt \& G. Ladd (Eds.), Peer relationships in child development (pp. 135-157). New York, NY: Wiley.

Denzin, N. K. (1978). The research act in sociology: A theoretical introduction to sociological methods ( $2 d$ ed.). New York, NY: McGraw-Hill.

Dörnyei, Z. (2007). Research methods in applied linguistics. Quantitative, qualitative, and mixed methodologies. New York, NY: Oxford University Press.

Eckerth, J. (2003). Fremdsprachenerwerb in aufgabenbasierten Interaktionen. Tübingen, Germany: Narr.

Ehlich, K., \& Rehbein, J. (1986). Muster und Institution: Untersuchungen zur schulischen Kommunikation. Tübingen, Germany: Narr.

Europarat (2001). Gemeinsamer europäischer Referenzrahmen für Sprachen: lehren, lernen, beurteilen. Berlin, Germany: Langenscheidt.

Feick, D. (2012). Videobasiertes lautes erinnern als Instrument zur Untersuchung fremdsprachlicher Gruppenaushandlungsprozesse. In S. Doff (Ed.), Fremdsprachenunterricht empirisch erforschen. Grundlagen methoden-anwendung (pp. 202-217). Tübingen, Germany: Narr.

Feick, D. (2014). Mobile Learning - Handyprojekte im Deutsch-alsFremdsprache- Unterricht. In N. Mackus \& J. Möhring (Eds.), WEGE öffnen für Bildung, Beruf und Gesellschaft - mit Deutsch als Fremd- und Zweitsprache, 38. Jahrestagung des Fachverbandes Deutsch als Fremdsprache an der Universität Leipzig (pp. 317-332). Göttingen, Germany: Universitäts verlag.

Feick, D. (2016). Autonomie in der Lernendengruppe. Entscheidungsdiskurs und Mitbestimmung in einem DaF- Handyvideoprojekt. Tübingen, Germany: Narr.

Feick, D. (2017). Emotionalität und Kooperation: affektive Aspekte von Gruppenarbeit (sichtbar machen). ÖDaF-Mitteilungen, 33(2), 23-34. 
Fiehler, R. (1978). Kommunikative Bedingungen kooperativer Prozesse (pp. 143-153). In M.-E. Conte, R. Giacalone \& P. Ramat (Eds.), Sprache im Kontext. Akten des 12. Linguistischen Kolloquiums Paiva 1978, Germany, Tübingen: Niemeyer.

Grießhaber, W. (1987). Authentisches und zitierendes Handeln. 1. Einstellungsgespräche. Tübingen: Narr.

Gunnarsson, M. (2006). Group decision-making. Language and interaction. Göteborg, Sweden: Department of Linguistics, Göteborg University.

Holec, H. (1981). Autonomy and foreign language learning. Prepared for the Council of Europe. Oxford, UK: Pergamon Press.

Holliday, A. (2003). Social autonomy: Addressing the dangers of culturism in TESOL. In D. Palfreyman \& R. C. Smith (Eds.), Learner autonomy across cultures. Language education perspectives (pp. 110-126). New York, NY: Palgrave Macmillan.

Hohenstein, C. (2006). Erklärendes Handeln im Wissenschaftlicher Vortrag: Ein Vergleich des Deutschen mit dem Japanischen. München, Germany: iudicium.

Kameyama, S. (2004). Verständnissicherndes Handeln: Zur reparativen Bearbeitung von Rezeptionsdefiziten in deutschen und japanischen Diskursen. Münster, Germany: Waxmann.

Kluge, S. (1999). Empirisch begründete Typenbildung. Zur Konstruktion von Typen und Typologien in der qualitativen Sozialforschung. Opladen, Germany: Leske und Budrich.

Knoblauch, H. (2006). Videography. Focused Ethnography and Video Analysis. In T. Knoblauch, H. B. Schnettler, J. Raab \& H. G. Soeffner (Eds.), Video analysis: methodology and methods. Qualitative audiovisual data analysis in sociology (pp. 69-83). Frankfurt, Germany: Lang.

Knorr, P., \& Schramm, K. (2012), Datenerhebung durch Lautes Denken und Lautes Erinnern in der fremdsprachendidaktischen Empirie. In S. Doff (Ed.), Fremdsprachenunterricht empirisch erforschen: Grundlagen, Methoden, Anwendung (pp. 184-201). Tübingen, Germany: Narr.

Lave, J., \& Wenger, E. (1991), Situated learning. Legitimate peripheral participation. Cambridge, UK: Cambridge University Press.

Legenhausen, L. (2010). Group work, weak learners and the autonomous classroom: indirect support for the interaction hypothesis? In B. O'Rourke \& L. Carson (Eds.), Language learner autonomy. Policy, curriculum, classroom: A Festschrift in Honour of David Little (pp. 29-44). Oxford, UK: Lang. 
Li, M., \& Zhu, W. (2017). Good or bad collaborative wiki writing: Exploring links between group interactions and writing products. Journal of Second Language Writing, 35, 38-53. doi:10.1016/j.jslw.2017.01.003

Little, D. (2000). Learner autonomy and human interdependence: Some theoretical and practical consequences of a social-interactive view of cognition, learning and language. In T. Lamb, I. McGrath \& B. Sinclair (Eds.), Learner autonomy, teacher autonomy: Future directions (pp. 1523). London, UK: Longman.

Long, M. (1996). The role of the linguistic environment in second language acquisition. In R. William \& B. Tej (Eds.), Handbook of second language acquisition (pp. 413-468). San Diego, California: Academic Press.

O’Leary, C. (2014). Developing autonomous language learners in HE: A social constructive perspective. In G. Murray (Eds.), Social dimensions of autonomy in language learning (pp. 15-36). Basingstoke, UK: Palgrave Macmillan.

Rehbein, J., Schmidt, T., Meyer, B., Watzke, F. \& Herkenrath, A. (2004). Handbuch für das computergestützte Transkribieren nach HIAT. Universität Hamburg: Sonderforschungsbereich Mehrsprachigkeit.

Simmons, D., \& Wheeler, S. (1995). The Process Syllabus in action. Sydney, Australia: National Centre for English Language Teaching and Research

Schmenk, B. (2008). Lernerautonomie. Karriere und Sloganisierung des Autonomiebegriffs. Tübingen, Germany: Narr.

Storch, N. (2001) How collaborative is pair work? ESL tertiary students composing in pairs. Language Teaching Research, 5(1), 29-53. doi:10.1177/136216880100500103

Storch, N. (2002a). Patterns of Interaction in ESL Pair work. Language Learning, 52(1), 119-158. doi:10.1111/1467-9922.00179

Storch, N. (2002b). Relationships formed in dyadic interaction and opportunity for learning. International Journal of Educational Research, 37(3-4), 305-322. doi:10.1016/s0883-0355(03)00007-7

Thornbury, S. (2011). Afterword: Dogme for beginners - the autonomy of the group. In K. Irie \& A. Stewart (Eds.), Realizing autonomy: Practice and reflection in language education contexts (pp. 257-266). Basingstoke, UK: Palgrave Macmillan.

Wygotski, L. S. (1934/2002). Denken und Sprechen. Edited and translateted from Russian by Joachim Lompscher and Georg Rückriem. Weinheim, Basel, Germany: Beltz.

\section{Appendices}


SiSAL Journal Vol. 9, No. 2, September 2018, 280-305.

Appendix A

Phases of the mobile phone video project (slightly adapted from Feick 2014: 324)

\begin{tabular}{|c|c|}
\hline Phase & Activity \\
\hline \multirow[t]{3}{*}{1 preparation } & $\begin{array}{l}\text { Elaboration, or rather repetition of topic-specific } \\
\text { vocabulary about film-making }\end{array}$ \\
\hline & introduction to film theory and practice \\
\hline & introduction to group work techniques \\
\hline \multirow[t]{2}{*}{2 introduction } & formation of project groups \\
\hline & $\begin{array}{l}\text { clarification of framework condition, such as project } \\
\text { concept, distribution of roles in the groups, } \\
\text { topic identification and forms of presentation }\end{array}$ \\
\hline \multirow{5}{*}{$\begin{array}{l}3 \text { planning and } \\
\text { organization }\end{array}$} & task distribution in the group \\
\hline & brainstorming and development of the synopsis \\
\hline & development of the script or interview questions \\
\hline & development of shooting schedule and/or storyboard \\
\hline & selection and acquisition of technical tools \\
\hline \multirow[t]{2}{*}{4 realization } & production: shooting \\
\hline & $\begin{array}{l}\text { post production: introduction to the editing software, editing, } \\
\text { sound editing, if necessary, subtitling }\end{array}$ \\
\hline 5 presentation & presentation of clips (internal and public) \\
\hline \multirow[t]{2}{*}{6 evaluation } & determination of evaluation criteria \\
\hline & oral and written evaluation \\
\hline
\end{tabular}




\section{Appendix $B$}

Video-based stimulated recall, instruction for the VSR assistant (translated from German and Spanish)

\section{1. explanation}

Even though we are speaking German in the project, you can speak Spanish now. We will watch the video now. We would like to know what you were thinking in the moment of the conversation. We can hear what you are saying when we watch the video but we don't know what you were thinking there. So, I would like you to tell me what you were thinking, what was going on in your head while you were talking with the other group members.

We will sit in front of the computer and I would like you to stop the video as soon as you remember anything. So, if you can tell me anything about what you have

been thinking in a certain moment, you shall press the pause button and then the recording starts. It is important not to speak over the running video but always stop the video tape. Do you have any questions about the procedure?

\section{2. exercise}

Practice once how the video can be stopped and the recording is started. After the test recording make sure that the participant has understood the procedure. The participant can stop the video as often as he/she likes. When the participant stops the video listen to him/her. If he/she starts talking while the video is still running, stop it and start the recording for her/him. Remind her/him to always press play when he/she has finished an utterance.

Furthermore don't react directly to the utterances of the participants. Non-verbal reactions or non-answers are preferable, like

aha, $\mathrm{mhm}$

Verstehe/ Entiendo (I understand)

o.k./ Bueno/ Ya/Listo/ De acuerdo... Ah ja/ Ah si. (good, ah yes)

When the participant has seen the video completely ask her/him if she/he has more comments or questions about the video or the task. After that you can ask additional questions like:

Is there anything else that you thought during the conversation or group work? Is there anything else you want to mention?

\section{3. debriefing}




\section{Transcription with HIAT}

Tier types and order (Rehbein et al.: 2004: 74- 75):

\begin{tabular}{|c|c|c|c|c|}
\hline label & type & $\begin{array}{l}\text { cate- } \\
\text { gory }\end{array}$ & $\begin{array}{l}\text { display } \\
\text { name }\end{array}$ & features \\
\hline $\begin{array}{l}\text { tier for speech- } \\
\text { accompanying } \\
\text { non-phonological, } \\
\text { acoustic } \\
\text { phenomena }\end{array}$ & annotation & sub & LULO[sup] & $\begin{array}{l}\text { e.g. laughing or } \\
\text { coughing }\end{array}$ \\
\hline verbal tier & $\begin{array}{l}\text { transcriptio } \\
\mathrm{n}\end{array}$ & $\mathrm{v}$ & LULO[v] & $\begin{array}{l}\text { for verbal spoken } \\
\text { utterances }\end{array}$ \\
\hline $\begin{array}{l}\text { tier for non- } \\
\text { speech- } \\
\text { accompanying } \\
\text { non- phonological- } \\
\text { acoustic } \\
\text { phenomena }\end{array}$ & $\begin{array}{l}\text { transcriptio } \\
\mathrm{n}\end{array}$ & $\mathrm{v}$ & LULO[v] & $\begin{array}{l}\text { e.g. drinking, } \\
\text { writing }\end{array}$ \\
\hline non-verbal tier & description & nv & LULO[nv] & $\begin{array}{l}\text { non-verbal } \\
\text { communication, e.g. } \\
\text { mimics, gesture, } \\
\text { gaze }\end{array}$ \\
\hline translation tier & annotation & ger/eng & LULO[ger] & $\begin{array}{l}\text { translation from } \\
\text { Spanish }\end{array}$ \\
\hline comment & annotation & k/VLE & $\begin{array}{l}\text { LULO } \\
\text { [VLE- Sp] }\end{array}$ & $\begin{array}{l}\text { comments in form of } \\
\text { VLE are outside of } \\
\text { the musical score } \\
\text { frame in the original } \\
\text { language [Sp] and in } \\
\text { the translation [Dt] }\end{array}$ \\
\hline
\end{tabular}

Transcription symbols (HIAT, Rehbein et al. 2004) 
SiSAL Journal Vol. 9, No. 2, September 2018, 280-305.

\begin{tabular}{|c|c|c|}
\hline name of the symbol & orthographic sign & explanation \\
\hline utterance end symbol &.$! ? \ldots$ & $\begin{array}{l}\text { these symbols mark the end of } \\
\text { utterance; } \\
\ldots \text { an utterance is ended by } \\
\text { being broken off; }\end{array}$ \\
\hline space symbol & & $\begin{array}{l}\text { follows obligatorily every } \\
\text { utterance end symbol }\end{array}$ \\
\hline $\begin{array}{l}\text { double parentheses } \\
\text { (open, closed) }\end{array}$ & $((())$ & $\begin{array}{l}\text { count as non-phonological } \\
\text { segment and are treated as } \\
\text { utterances; }() \text { utterance is hard } \\
\text { to understand; }(()) \\
\text { unintelligible utterance }\end{array}$ \\
\hline $\begin{array}{l}\text { miscellaneous } \\
\text { punctuation }\end{array}$ &, 1 & / marks repairs \\
\hline pause symbols & $\bullet \quad \bullet \bullet \bullet$ & $\begin{array}{l}\text { very short but audible; short; } \\
\text { half a second }\end{array}$ \\
\hline $\begin{array}{l}\text { Interjections in the class } \\
\text { of HM, macron }\end{array}$ & & monotonical „Hm“ \\
\hline
\end{tabular}

